Swarthmore College

Works

1985

\title{
Transnational Corporations Versus The State: The Political Economy Of The Mexican Auto Industry
}

D. C. Bennett

Kenneth Evan Sharpe

Swarthmore College, ksharpe1@swarthmore.edu

Follow this and additional works at: https://works.swarthmore.edu/fac-poli-sci

Part of the Political Science Commons

Let us know how access to these works benefits you

\section{Recommended Citation}

D. C. Bennett and Kenneth Evan Sharpe. (1985). "Transnational Corporations Versus The State: The Political Economy Of The Mexican Auto Industry". Transnational Corporations Versus The State: The Political Economy Of The Mexican Auto Industry.

https://works.swarthmore.edu/fac-poli-sci/354

This work is brought to you for free by Swarthmore College Libraries' Works. It has been accepted for inclusion in Political Science Faculty Works by an authorized administrator of Works. For more information, please contact myworks@swarthmore.edu. 


\section{Chapter Title: INTRODUCTION}

Book Title: Transnational Corporations versus the State Book Subtitle: The Political Economy of the Mexican Auto Industry

Book Author(s): DOUGLAS C. BENNETT and KENNETH E. SHARPE

Published by: Princeton University Press. (1985)

Stable URL: https://www.jstor.org/stable/j.ctt7ztjh9.6

JSTOR is a not-for-profit service that helps scholars, researchers, and students discover, use, and build upon a wide range of content in a trusted digital archive. We use information technology and tools to increase productivity and facilitate new forms of scholarship. For more information about JSTOR, please contact support@jstor.org.

Your use of the JSTOR archive indicates your acceptance of the Terms \& Conditions of Use, available at https://about.jstor.org/terms

Princeton University Press is collaborating with JSTOR to digitize, preserve and extend access to Transnational Corporations versus the State 


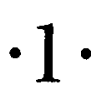

\section{INTRODUCTION}

In 1960, the automobile industry in Mexico consisted of a dozen small firms that assembled vehicles from imported kits. By 1970, there was substantial automobile manufacture in Mexico: 60 percent of each vehicle sold in Mexico was produced there. By 1980, Mexico had become a significant exporter of automotive parts, particularly to the United States. Cars "made in the U.S." had a fair chance of containing Mexican-built engines, springs, windshields, or transmissions, and automotive exports had become a point of friction between the U.S. and Mexican governments. Moreover, during these years, the automobile industry was the engine for a new surge of industrial growth in the Mexican economy. This book explores this transformation at three levels:

First, it aims to provide a historical account of the growth of automobile manufacturing in Mexico, a significant element in the industrialization of the country and an important chapter in the history of the internationalization of the automobile industry.

Second, it aims to understand bargaining and dependency relations between transnational corporations (TNCS) and the state in developing countries. The coming of automobile manufacture to Mexico has been accompanied by a steadily increasing domination by transnational firms-Ford, General Motors, Chrysler, Volkswagen, Nissan, Renault, and American Motors. Nevertheless, the development of automobile manufacture would not have occurred without the continuous exertions of the Mexican state. The twenty-year history of the automobile industry in Mexico thus provides an unusually rich case for examining bargaining between states and TNCs in the overall context of the dependency of a developing country.

Third, most generally and for us most importantly, it seeks to exemplify a historical-structural method, demonstrating the ability of this approach to address the fundamental issues of social-science inquiry. The approach, simply stated, follows Marx's maxim: "Men make their own history, but they do not make it just as they please; they do not make it under circumstances chosen by themselves, but under circumstances directly found, given and transmitted from the past."1

\footnotetext{
${ }^{1}$ Karl Marx, "The Eighteenth Brumaire of Louis Bonaparte," in Robert C. Tucker, ed., The Marx-Engels Reader (New York: W. W. Norton, 1972), p. 437.
} 
However much this may seem like common sense, it is decidedly not the established position in the social sciences, particularly in the United States. All too often, theorists a priori assume either that there are certain historical laws or social structures that determine and thus explain human action, or that individuals or groups exercising their free will can voluntaristically re-create themselves or society. Our intention is to use a historical-structural method that is neither deterministic nor voluntaristic. We will explore what possibilities for human action are open or closed at a particular time within given social structures; we will try to explain the interests of actors and their power to create change within these historical limits; and we will look at how actions taken over time (i.e., human history) change or maintain social structures, which themselves open possibilities for, as well as limit, future action.

The structures with which we are most concerned are those of capitalism as a world system. These are the structures that define dependency in less-developed countries (LDCs). Proceeding from our historical-structural approach, we see these as constricting but not determining the chances for development. There are possibilities for action-in this case, by the state-to make development happen. But whether this development can be rapid and whether its fruits can be equitably shared are among the questions for our analysis.

\section{BARGAINING AND DEPENDENCY}

Three episodes of bargaining between the Mexican state and the transnational automobile firms were particularly important in moving the automobile industry in Mexico from simple assembly to domestic manufacture to exports. These three bargaining conflicts and the changes they brought about are the substance of our narrative. The central actors were the Mexican government and the transnational automobile firms, but Mexican entrepreneurs and the home-country governments of the TNCs played important supporting roles. Though vital to the development of the industry, labor in Mexico was never involved in shaping industrial policy toward the automobile sector. Bargaining among the key actors moved the industry forward from assembly to domestic manufacture to exports, but this bargaining took place within structures that were both national and international. The political economy of Mexico has been continually shaped by its dependent relationships with the world capitalist system, and the Mexican automobile industry by its dependent relationships with the world auto industry. 
These complex structures delimited the alternatives and shaped the interests of the actors and their power to choose among them.

Our analysis proceeds, though not uncritically, within the broad perspective of dependency theory. The theory of modernization of the 1950s and 1960s sought to explain underdevelopment by viewing some countries as simply starting later and proceeding more slowly than others along the path to development because of an adherence to traditional values and institutions. ${ }^{2}$ In this perspective, all countries follow essentially the same route to "modernity." By contrast, the dependency perspective argues that the earlier development of some countries significantly alters the terms and chances of development of others. "Underdevelopment" in Latin America, Africa, and Asia (the "periphery") is not an inherent condition but rather a consequence of the earlier "development" of Europe and North America (the "center") and of the integration of the peripheral countries into a capitalist world economy on terms which are generally disadvantageous to them. In this perspective, Mexico is not simply "behind," nor can it simply follow in the footsteps of the United States. Rather, relationships with the industrialized countries hinder the development of those following after them. The complex and often subtle ways that such relationships impede development have been the primary concern of the dependencia perspective.

Central to this perspective is capitalism viewed as a world system. The intellectual origins of the dependencia framework were rooted in the concern of Latin American scholars for the domestic consequences of imperialism. The world capitalist system, the dependency approach argues, is "characterized by a functional division of labor" between the center and the periphery.

Countries of the center are industrially advanced and viewed as capable of developing dynamically in accordance with their internal needs; they are the main beneficiaries of global links. The periphery has a less autonomous type of development, conditioned

${ }^{2}$ For explications of the modernization approach, see Gabriel A. Almond and James S. Coleman, eds., The Polutes of Developing Areas (Princeton: Princeton University Press, 1960); Walt W. Rostow, The Stages of Economic Growth: A Non-Communest Mantesto (Cambridge: Cambridge University Press, 1960); and Cyril E. Black, The Dynamess of Modernzzatzon (New York: Harper and Row, 1966). Important critıques of the modernization theory include Remhard Bendix, "Tradition and Modernity Reconsidered," Comparative Studzes in Soczety and History 9 (1967):292-346; Joseph R. Gusfield, "Tradition and Modernity: Misplaced Polarities in the Study of Social Change," American Journal of Sociology 72 (1967):351-362; and Robert A. Packenham, Liberal Amerca in the Therd World (Princeton: Princeton University Press, 1973). 


\section{INTRODUCTION}

by the requirements of the center's expansion. Dependency analysis attempts to understand, and evaluate, the developmental implications of peripheral capitalism. ${ }^{3}$

Simply stated, dependency is a situation "in which the rate and direction of accumulation are externally conditioned." Dependency is not inconsistent with development: there may be significant economic growth, as there has been in Mexico over the past half-century. It is rather that actors and processes outside the country undergoing development are principally responsible for setting the opportunities for and the limits to development. Nor does external conditioning mean that the benefits of development accrue only to those outside the country. The dependency perspective is concerned with the internal analogies of external structures and processes. Relationships of dependency serve to benefit a domestic elite that draws wealth and power from its privileged position within the linkages that tie a developing country to the world capitalist system.

This external conditioning is largely defined by a complex web of international relationships between center and periphery, involving trade, finance, and investment, which have varied in their relative

${ }^{3}$ Gary Gereffi, The Pharmaceutucal Industry and Dependency in the Third World (Princeton: Princeton University Press, 1983), pp. 7-8.

${ }^{4}$ Peter Evans, Dependent Development: The Alliance of Multmational, State, and Local Captal in Brazul (Princeton: Princeton University Press, 1979), p. 27. Compare the more elaborate definition of Theotonio dos Santos: "By dependence we mean a situation in which the economy of certain countries is conditioned by the development and expansion of another economy to which the former is subjected. The relation of interdependence between two or more economies, and between these and world trade, assumes the form of dependence when some countries (the domınant ones) can expand and be self-sustaining while other countries (the dependent ones) can do this only as a reflection of that expansion, which can have either a positive or a negative effect on their immediate development." Theotonıo dos Santos, "The Structure of Dependence," Amerncan Economic Revnew 60 (1970):236. Other important treatments of dependencia are: Celso Furtado, Economic Development of Latin Amenca: A Survey from Colonial Times to the Cuban Revolution (London: Cambridge University Press, 1970); Helıo Jaguaribe, Econome and Polatical Development: A Theoretncal Approach and a Brazuluan Case Study (Cambridge: Harvard Unıversity Press, 1968); Frank Bonilla and Robert Girlin, eds., Structures of Dependency (Stanford: Stanford University Press, 1973), Suzanne Bodenheimer, "Dependency and Imperialism: The Roots of Latin American Underdevelopment," in K. T. Fann and Donald C. Hodges, eds., Readings in U.S. Imperialısm (Boston: Porter Sargent, 1971), pp. 155-181; André Gunder Frank, Captalusm and Underdevelopment in Latin Amenca: Hustorical Studues of Chule and Brazal (New York: Monthly Review Press, 1967); James T. Petras, Laton Amenca: From Dependence to Revolution (New York: John Wiley, 1973); Osvaldo Sunkel, "Bıg Business and 'Dependencia'," Foretgn Affairs 50 (1972):517-531; and Fernando Henrique Cardoso and Enzo Faletto, Dependency and Development in Latin Amerca (Berkeley and Los Angeles: University of California Press, 1979). 
importance but which have tended to reinforce one another. Since World War II, investments by transnational corporations have been particularly critical in shaping situations of dependency. Whereas direct foreign investment was once confined primarily to mining and agriculture, and to activities closely connected with these, such as railroads, direct foreign investment in manufacturing has been dominant in recent decades. These investments were triggered in part by import substitution policies of LDCs that were seeking to induce domestic manufacturing and thus to lessen trade dependency (the export of primary products to pay for imports of manufactured goods), but they stemmed as well from the postwar international expansion of transnational corporations based in the U.S., Europe, and Japan.

While the modernization approach has tended to see rNCs as beneficent agents of change bringing capital, technology, and management skills to LDCs, the dependency approach has inclined toward a more critical view, arguing that investments by rNcs have posed a threat to domestic capital accumulation and that manufacturing industries in LDCs have been shaped more in response to world market conditions and the global strategies of TNCs than in response to the needs of the populations of developing countries. One important concern of the dependency approach with transnational corporations has to do with their consequences for distribution. TNCs, it is argued, not only impede national accumulation, but they also foster an inequitable international distribution of income by shifting capital from developing to developed countries (through profit repatriation, payments for technology, and sales of parts and equipment). Further, it is argued that TNCs reinforce an inequitable distribution of income within developing countries. Important as this concern is, it is not the one on which we will primarily focus. Our main interest, rather, lies in the possible distortions of an LDC's economy, society, and politics that can follow from the activities of TNCs. Transnational corporations, it has been argued, are unwilling to invest in activities that would promote growth and industrialization. They utilize inappropriate (capital-intensive) technology and introduce inappropriate products into LDCs. Further, they prevent the development of an indigenous economic base, squeezing out local entrepreneurs or pre-empting their entry into the most dynamic sectors of the economy; and they distort local market structures, visiting upon LDCs the oligopolistic structures and practices of globally organized industries. Finally, it is claimed, TNCs co-opt local elites or form alliances with domestic entrepreneurs to block government efforts at regulation, and they use their influence with home-country governments to keep host-country governments in line. 
These hypothesized distortions will be foremost in our attention as we examine the consequences of TNC activities during two decades of development of the automobile industry in Mexico. The nature of these consequences has depended not only on the actions of the transnational automobile corporations, however, but also on the actions of the Mexican state. There has been a decided tendency in dependencia analyses to depict the state as passive and powerless in the face of the TNCs, not as an actor able or inclined to oppose them in any significant respect. In this work, we proceed from a different assumption: that in certain circumstances, the state in developing countries can and will attempt to alter the behavior of TNCs and the consequences of that behavior. It may even seek to alter some of the structural aspects of dependency in which TNCs have a substantial stake. Exploring this assumption requires attention to bargaining between the state and TNCs.

This study seeks to advance the understanding of dependency and development processes in a number of different ways:

(1) It focuses on a single industry over two decades of growth and change. Dependency studies that take entire countries as their focus of analysis tend to sketch the mechanisms of dependency only in very broad strokes. Studies of single industries can provide a much clearer understanding of the predicaments faced by specific actors and what they can and cannot do in them. On the other hand, studies of single industries within the dependency perspective have largely been restricted to the extractive industries. We focus on a manufacturing industry because this has been the most dynamic sector of foreign investment in recent decades and because the lack of industrialization was a defining feature of dependency before World War II that many third-world governments have sought to overcome. Furthermore, the particular industry examined, automobile manufacture, is one that has gone through significant changes in its global organization, thus allowing us to follow the consequences of changes in international structure for actors in Mexico.

(2) It pays particular attention to public policy toward the industry. Many dependency studies concentrate so much on the structural constraints that define situations of dependency, or presume the state to be so passive, that they fail to make a serious inquiry into public policy. The automobile industry in Mexico has been an object of government policy for the past quarter-century. We want to analyze not only the constraints imposed by situations of dependency but also the alternatives for action within these constraints and the consequences of choices made. At least in the Mexican case, this requires an examination of the making and implementing of public policy. 
(3) For related reasons, this study pays particular attention to bargaining between the Mexican state and the transnational automobile firms. The Mexican state has by no means been able to establish by fiat whatever policy it chooses. Instead, it has had to negotiate with the transnational automobile firms. Although there have been a number of excellent studies of bargaining between third-world governments and transnational firms, these have not been fully integrated into the dependency perspective.

(4) It is a case study of the limits of possibility for a state seeking to overcome dependency while abiding by the norms of global capitalism. The Mexican government has not attempted to remove Mexico from the world capitalist system. Rather, it has pursued policies aimed at providing both growth and increased autonomy for Mexico within that system, and nowhere has this been more evident than in the automobile industry. Our study therefore is a kind of test case for the dependency perspective.

(5) It employs a historical-structural approach that gives equal emphasis to structures and actions, to limits and possibilities. A historical-structural approach is already embodied in the best examples of the dependency perspective; what we seek now to contribute is a deliberate and consistent application of this approach to both of our principal actors, the Mexican state and the transnational automobile corporations.

\section{The Historical-Structural Approach}

Taken together, dependency and bargaining manifest the central methodological perspective of this book-the historical-structural approach. The dominant approaches in American social science have tended toward either determination or voluntarism and have thus led to fundamental distortions of the human condition and subtle betrayals of the proper aims of social analysis. In contrast, the historical-structural approach holds that human beings are social products, but that society itself is a product of human actions. In the words of Cardoso and Faletto, this approach "emphasizes not just the structural conditioning of social life, but also the historical transformation of structures by conflict, social movements and class struggles." ${ }^{5}$

The dependency perspective places particular emphasis on structures-particularly the structures of the world capitalist system - that "condition" development. These structures, to quote Cardoso and Fa-

\footnotetext{
${ }^{5}$ Cardoso and Faletto, Dependency and Development in Latın Amenca, p. x.
} 
letto again, "impose limits on social processes and reiterate established forms of behavior." In the hands of some dependency analysts, this structural conditioning tends toward a certain determinism; possibilities for significant choice within these structures and for action to transform structures are denied. We are interested, however, in the possibilities for change within and against existing structures. Structures condition but do not fully determine; they impose limits but also shape possibilities. The task for social analysis is to explore, concretely, the structural limits and the possibilities for action in particular historical situations. Our emphases on state policy and on bargaining are intended to make explicit these concerns with alternative possibilities and with the transformation of structures.

Structures shape the interests and power of the actors within them. Insofar as structures bequeath overwhelming power to some actors or mold a fundamental convergence of interests among actors, structures will tend to persist. Efforts to alter them will be ineffectual. However, structures tend to "generate contradictions and social tensions" -i.e., conflicts of interest-and these set the stage for change. One major task of this study is to explain the interests of the Mexican state and the transnational automobile firms, to reach some understanding of how and why their interests converged at some points and diverged into conflict at others.

The historical-structural approach to the actors in a set of events proceeds from three leading ideas: (1) Each actor has interests and power of its own-the wherewithal to make its own history. (2) The possibilities for action are limited by the structures in which actors are enmeshed, and each actor's interests and power are shaped by its position within these structures. (3) These structures are historical products of past human actions and, in certain circumstances, are susceptible to marginal change or transformation by the concerted efforts of the actors.

For an elaboration of a historical-structural approach applied to transnational corporations, we turn to industrial-organization theory. First formulated in the United States and most widely employed in the study of the U.S. economy, industrial-organization theory has been used almost exclusively in the analysis of industries within the geographically constrained national market of a developed country. Because our concerns are with a developing country and with transnational corporations, which operate simultaneously in several different

${ }^{6}$ Ibid., p. xi.

${ }^{7}$ Ibid. 
national markets, several revisions of industrial-organization theory will be necessary to fit it to our purposes.

The structure most important (though hardly the only one) in shaping the interests and power of the transnational automobile firms in the Mexican setting is the structure of the industry in which they compete, both globally and in Mexico. Two aspects of this structure will be salient in our analysis: (a) the structure of the market, principally the number of firms in the industry, and (b) the structure of ownership, principally the extent of domination by transnational firms. These aspects of the Mexican automobile industry structure were in part the result of struggle between the state and the TNCs. Once created, they have been crucial in shaping the behavior of the firms and the performance of the industry in Mexico.

Unlike the case for the transnational firms, there is no single structure which is of pre-eminent importance in shaping the interests and power of the state or in delimiting its possibilities for action. The relevant structures are many: they are domestic and international, and they are political, economic, social, military, and cultural. Moreover, despite the renaissance of attention to "the state," there is no single theory of the state to which we can turn for an elaboration of the historical-structural approach; we have had to fashion our own, drawing on a number of perspectives.

Consistent with the historical-structural approach, we depict the state as an actor with interests and power of its own-a conception that is denied, explicitly or implicitly, by a number of current perspectives. This hardly means the state can act "just as it pleases," nor is it an insistence on the autonomy of the state. While state action may be shaped and constrained, for example, by its relationship to the domestic class structure or to the structure of international finance, the state is nevertheless an actor, capable of formulating its own policies and of exerting power in an effort to carry them through.

Our approach to the state understands its interests as being "embedded orientations" that have been acquired and institutionalized in the course of its history as the state has responded to problems and opportunities facing it. The power of the state is set both by internal characteristics (unity, technical capability) and by its relationship to the structures around it, particularly the domestic class structure. In the Mexican situation, it is particularly important to see the active role of the state in shaping this relationship to domestic classes; it has not merely been an object that was captured or shaped in the conflict among them.

The historical-structural approach—this concern with structure and 
action, with dependency and bargaining-informs the organization of this book. Chapters 2 through 4 introduce the major actors and the structures within which they are enmeshed, and it sets forth in greater detail the theoretical perspectives that guide our analysis. Chapter 2 provides an overview of the political economy of Mexico, focusing on the changing character of dependency within the world capitalist system, and lays out our theoretical approach to the Mexican state as an actor. Chapter 3 does the same for the world automobile industry, showing Mexico's place within that structure in 1960 and setting forth our theoretical approach to the transnational automobile corporations. Chapter 4 elaborates our framework for the analysis of bargaining between the state and transnational corporations.

Drawing on this foundation, chapters 5 through 10 analyze dependency and bargaining in the automobile industry in Mexico between 1960 and 1980, concentrating on three major episodes. For each, we will (a) examine the structures that determined the limits and possibilities for action and shaped the interests and power of the actors, (b) examine the conflict itself and show how its resolution led to change or continuity in the structure of the automobile industry in Mexico, and (c) show how this new structure set the stage for the next conflict, imposing new limitations but opening other possibilities for action. Chapters 5 and 6 are concerned with the 1962 bargaining: the effort of the Mexican state to create a manufacturing industry in Mexico by means of an import-substitution policy, the resulting enactment and implementation of a governmental decree, and the structure of ownership and of the market that resulted. Within these new structures, there arose a series of problems for the state and for some of the firms, particularly the Mexican-owned ones. Chapters 7 and 8 deal with a second major conflict in 1968-1969, growing out of these problems. The bargaining that took place in this connection led to a decision to move away from import substitution and toward export promotion as the basic thrust of policy. The chapters examine the difficulties this change engendered and the way in which the problems were rendered more serious by a crisis in the political economy of Mexico in the mid1970 s, as well as a series of changes in the structure of the world automobile industry which had important implications for Mexico and the transnational corporations. Chapter 9 considers a third bargaining episode, in 1977, the result of which was a new decree strengthening export requirements, and chapter 10 treats a variety of problems that resulted from this Decree.

Chapter 11 draws a number of conclusions about the historical- 


\section{INTRODUCTION}

structural approach, the consequences of TNCs for developing countries, and the possibilities for altering these consequences by state action. In a postscript, we provide a brief discussion of a new automotive policy, promulgated in September 1983, while Mexico was in the midst of an economic crisis. 